\title{
AMENDMENTS
}

\section{Publisher Correction: Genomic insights into diverse bacterial taxa that degrade extracellular DNA in marine sediments}

Kenneth Wasmund (D), Claus Pelikan, Arno Schintlmeister, Michael Wagner, Margarete Watzka, Andreas Richter (iD, Srijak Bhatnagar (D), Amy Noel, Casey R. J. Hubert (D), Thomas Rattei (D), Thilo Hofmann (D), Bela Hausmann (D), Craig W. Herbold and Alexander Loy (iD

Correction to: Nature Microbiology https://doi.org/10.1038/s41564-021-00917-9, published online 14 June 2021.

This Article was originally published with an incorrect copyright status, and should have been Open Access. This error has now been corrected and the Article is now published under a Creative Commons licence CC BY 4.0.

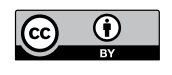

Open Access This article is licensed under a Creative Commons Attribution 4.0 International License, which permits use, sharing, adaptation, distribution and reproduction in any medium or format, as long as you give appropriate credit to the original author(s) and the source, provide a link to the Creative Commons license, and indicate if changes were made. The images or other third party material in this article are included in the article's Creative Commons license, unless indicated otherwise in a credit line to the material. If material is not included in the article's Creative Commons license and your intended use is not permitted by statutory regulation or exceeds the permitted use, you will need to obtain permission directly from the copyright holder. To view a copy of this license, visit http://creativecommons.org/licenses/ by $/ 4.0 /$.

Published online: 19 July 2021

https://doi.org/10.1038/s41564-021-00936-6

(C) The Author(s) 2021 